\title{
Blast Furnace Granulated Coal Injection
}

\author{
Quarterly Report \\ July 1 - September 30, 1998
}

Work Performed Under Contract No.: DE-FC21-91MC27362

\section{RECEIVEO \\ MAR O 21999 \\ OSTI}

\author{
For \\ U.S. Department of Energy \\ Office of Fossil Energy \\ Federal Energy Technology Center \\ P.O. Box 880 \\ Morgantown, West Virginia 26507-0880 \\ By \\ Bethlehem Steel Corporation \\ Bethlehem, Pennsylvania
}




\section{Disclaimer}

This report was prepared as an account of work sponsored by an agency of the United States Government. Neither the United States Government nor any agency thereof, nor any of their employees, makes any warranty, express or implied, or assumes any legal liability or responsibility for the accuracy, completeness, or usefulness of any information, apparatus, product, or process disclosed, or represents that its use would not infringe privately owed rights. Reference herein to any specific commercial product, process, or service by trade name, trademark, manufacturer, or otherwise does not necessarily constitute or imply its endorsement, recommendation, or favoring by the United States Government or any agency thereof. The views and opinions of authors expressed herein do not necessarily state or reflect those of the United States Government or any agency thereof. 


\section{DISCLAIMER}

Portions of this document may be illegible in electronic image products. Images are produced from the best available original document. 


\section{QUARTERLY REPORT}

\section{Plant Operations:}

Production levels on each furnace exceeded 7000 NTHM/day during July. The combined production of 14,326 was a result of lower coke rates and below average delay rates on both furnaces. The combined production was at its highest level since September 1997. In August, the combined productivity declined to less than $13,500 \mathrm{NTHM} /$ day. Although D furnace maintained a production rate in excess of 7000 NTHM/day, C furnace was lower because of a castfloor breakout and subsequent five day repair from August 26-30. Despite the lower productivity in August, injected coal and furnace coke rates were very good during the month. During September, the operation was difficult as a result of higher delays on both furnaces. The combined average monthly delay rate was considerably above the twenty-month average of 113 minutes per day and the combined average monthly production was less than 14,000 NTHM/day. Higher furnace coke rates at lower coal injection levels also contributed to the decrease. Additionally, the coke rate on both furnaces was increased substantially and the injected coal rate was decreased in preparation for the high volatile Colorado coal trial that started on September 28. The furnace process results for this quarter are shown in Tables 1A and 1B. In addition, the last twelve months of injected coal and coke rates for each furnace are shown in Figures 1 and 2.

The Colorado coal trial is part of the continuing cooperative agreement with the Department of Energy. The trial is expected to last about five weeks and will consist of three weeks using granular sizing and two weeks using pulverized sizing. For this trial the BALWAX model predicts that a higher coke rate will be necessary due to the lower carbon content of the Colorado coal. Therefore, beginning on September 10, the coke rate on both furnaces was increased by about 45 pounds/NTHM. The increase caused the monthly average coke rate to rise to 702 pounds/NTHM on $C$ and 729 pounds/NTHM on D in September. An evaluation of the effects of injected coal sizing on furnace operating parameters will be made by comparing furnace performance with granular coal to that of pulverized coal.

\section{Furnace Coke Evaluation:}

Since May 17, there have been several changes made to the coke charged to the Burns Harbor furnaces. The timing of these changes provided an opportunity to assess the furnace operation with the different cokes. The analysis is made using a comparative base period on $C$ furnace from April 1 through May 17. C furnace was analyzed since injected coal was used during all of the evaluation periods. The low volatile component of the coal blend at the coke ovens was increased from $25 \%$ to $30 \%$ on May 18 to start the first evaluation period. On July 5, Chinese coke was charged to the furnace. The rate of use was about $13.8 \%$ of the total coke consumed during the second evaluation period. Subsequently, on September 11 , the low volatile coal blend component was changed back to the original $25 \%$ level. The furnace statistics and the Burns Harbor coke stability are compared for the base period and the three evaluation periods in Table 2. The physical properties of the Chinese coke are also shown on Table 2. Because coke quality, particularly size and stability, can substantially affect the permeability of the furnace, permeability is the variable that is 
assessed during each evaluation period. Also, since injected natural gas increases furnace permeability, all operating days when natural gas was used on the furnace in excess of 5 pounds/NTHM are deleted from the evaluation data. The $t$ - statistic for differences between means with small sample sizes is used to determine the statistical validity of the evaluation periods. This method determines if the mean value between two samples is statistically different and at some confidence interval. If the t-statistic indicates that the permeability value changed, the period was examined for other process changes that may have affected the permeability besides the coke change. Each of these comparative periods has been examined in such a manner.

The evaluation base period is shown in Figure 3. The average furnace permeability with all home coke at a coal blend using $25 \%$ low volatile coal is 1.21 . The coal injection rate during this period is 297 pounds/NTHM. The Burns Harbor coke stability is 60.8 and 60.9 measured at the wharf on $\# 1$ and $\# 2$ batteries.

Figure 4 shows the first evaluation period using Burns Harbor coke after the change to $30 \%$ low volatile coal. The average permeability has increased to 1.28 . The coke stability increased on both \#1 and \#2 batteries to 61.6 and 62.1 respectively. This change in stability compared to the base period on each battery is statistically significant at the $99 \%$ confidence interval. The injected coal rate of 294 pounds/NTHM is comparable to the base period. The increase in permeability during this period is statistically significant at the $99 \%$ confidence interval. Since there were no other discernable process changes in the operation during this period, the increase in the furnace permeability is attributed to the change in coke stability.

Chinese coke was added to the burden on July 7. Table 2 shows that during the period from July 7 through September 11, the second evaluation period, Chinese coke was added at $13.8 \%$ of the total coke rate. Figure 5 shows the permeability results during the period. The increase from 1.28 to 1.34 is statistically significant at the $99 \%$ confidence level. Since the coal injection rate has not changed, the home coke stability has remained at the previous period's high level and no other process changes are apparent, the increase is attributed to the use of Chinese coke. Table 2 shows the physical properties of the Chinese coke that we believe increased the permeability. The Chinese coke is noticeably larger than home coke and has a higher stability. Also of importance is the small amount of this coke that is minus one inch. The amount of undersized coke that goes into the furnace may be more significant for permeability than the top size. Ultimately, however, the most important attribute of the Chinese coke that affects permeability is the stability value. The higher stability of the Chinese coke is primarily responsible for the increase in permeability. The third comparative period is shown in Figure 6. The low volatile coal in the blend was reduced to the previous level of $25 \%$ during this brief period in September but the coke stability did not change. The Chinese coke percentage in the burden increased slightly to $15.1 \%$ of the total coke rate and the coal injection rate was reduced by 60 pounds/NTHM. The furnace permeability has increased to 1.40 from 1.34 . The increase is statistically significant at the $99 \%$ confidence level. The reduction of the coal injection rate and the corresponding increase in the furnace coke rate was made to accommodate the planned Colorado coal trial mentioned previously. 
The change in permeability during this period is attributed to the injected coal and coke rate change rather than to a change in coal blend or the increase of Chinese coke

The increase in furnace permeability using higher stability coke with a tighter size range is not surprising. Since the beginning of coal injection, operators have struggled to maintain good furnace permeability. Higher coal injection rates and lower furnace coke rates are limited at the Bums Harbor furnaces by the permeability factor. The surprising result of this analysis is that small, incremental differences in coke properties can significantly affect the permeability.

Plans for Next Quarter:

Complete the Colorado coal trial with granular and pulverized coal. 
TABLE 1A

\section{Burns Harbor C Furnace}

Summary of Operation

\begin{tabular}{|c|c|c|c|}
\hline & July 98 & Augus: 98 & Sept 98 \\
\hline Prod, NTHM/d Rep & 7256 & $64 C^{-}$ & 6835 \\
\hline Delays, Min/d & 45 & $15 \vdots$ & 71 \\
\hline Coke Rate, Ibs/NTHM & 644 & $66 \hat{c}$ & 702 \\
\hline Nat. Gas Rate, Ibs/NTHM & 8 & 10 & 8 \\
\hline Inj. Coal Rate, Ibs/NTHM & 287 & 282 & 254 \\
\hline Total Fuel Rate, Ibs/NTHM & 938 & $96 C$ & 964 \\
\hline \multicolumn{4}{|l|}{ Burden \%: } \\
\hline Sinter & 35.8 & $31 . \hat{8}$ & 33.1 \\
\hline Pellets & 64.0 & 68. & 66.7 \\
\hline Misc. & .2 & .2 & .2 \\
\hline BOF Slag, IbsiNTHM & 4 & 9 & 9 \\
\hline \multicolumn{4}{|l|}{ Blast Conditions: } \\
\hline Dry Air, SCFM & 145,851 & 146,637 & 151,533 \\
\hline Blast Pressure, psig & 38.3 & 38.2 & 38.6 \\
\hline Permeability & 1.34 & 1.33 & 1.40 \\
\hline Oxygen in Wind, \% & 26.4 & 25.9 & 25.1 \\
\hline Temp, F & 2101 & 2087 & 2090 \\
\hline Moist., Grs/SCF & 22.8 & 20.4 & 20.5 \\
\hline Flame Temp, F & 3811 & 3783 & 3831 \\
\hline Top Temp, F & 256 & 261 & 257 \\
\hline Top Press, psig & 16.7 & 16.5 & 17.2 \\
\hline \multicolumn{4}{|l|}{ Coke: } \\
\hline $\mathrm{H} 2 \mathrm{O}, \%$ & 4.9 & 4.8 & 5.1 \\
\hline \multicolumn{4}{|l|}{ Hot Metal, \%: } \\
\hline Silicon & .51 & .55 & .53 \\
\hline Standard Dev. & .123 & .167 & .152 \\
\hline Sulfur & .035 & .034 & .034 \\
\hline Standard Dev. & .015 & $.01 E$ & .020 \\
\hline Phos. & .058 & $.05 \varepsilon$ & .060 \\
\hline $\mathrm{Mn}$ & .38 & .38 & .40 \\
\hline Temp., $F$ & 2700 & $266 \hat{\varepsilon}$ & 2661 \\
\hline \multicolumn{4}{|l|}{ Slag, \%: } \\
\hline $\mathrm{SiO} 2$ & 36.94 & $36.8 \Xi$ & 37.02 \\
\hline Al2O3 & 9.78 & $9.5 \hat{i}$ & 9.63 \\
\hline $\mathrm{CaO}$ & 40.18 & $40.2 \hat{z}$ & 39.94 \\
\hline $\mathrm{MgO}$ & 11.39 & 11.22 & 11.47 \\
\hline $\mathrm{Mn}$ & .34 & .36 & .37 \\
\hline Sul & 1.47 & 1.47 & 1.48 \\
\hline$B / A$ & 1.10 & $1.1^{\circ}$ & 1.10 \\
\hline$B / S$ & 1.40 & $1.3 \mathrm{C}$ & 1.39 \\
\hline Volume, Ibs/NTHM & 438 & 434 & 435 \\
\hline
\end{tabular}


TABLE 1B

Burns Harbor D Furnace

Summany of Operation

\begin{tabular}{|c|c|c|c|}
\hline & July 98 & August 98 & Sept 98 \\
\hline Prod. NTHM/d Rep & 7070 & 7078 & 6838 \\
\hline Delays, Min/d & 50 & 42 & 81 \\
\hline Coke Rate, Ibs/NTHM & 678 & 683 & 729 \\
\hline Nat. Gas Rate, Ibs/NTHM & 5 & 2 & 1 \\
\hline Inj. Coal Rate, lbs/NTHM & 243 & 250 & 222 \\
\hline Total Fuel Rate, Ibs/NTHM & 927 & 935 & 951 \\
\hline \multicolumn{4}{|l|}{ Burden \%: } \\
\hline Sinter & 34.9 & 30.8 & 32.2 \\
\hline Pellets & 65.0 & 69.0 & 67.6 \\
\hline Misc. & .2 & .2 & .2 \\
\hline BOF Slag, Ibs/NTHM & 5 & 10 & 10 \\
\hline \multicolumn{4}{|l|}{ Blast Conditions: } \\
\hline Dry Air, SCFM & 145,943 & 149,599 & 151,916 \\
\hline Blast Pressure, psig & 38.3 & 37.6 & 38.1 \\
\hline Permeability & 1.32 & 1.43 & 1.44 \\
\hline Oxygen in Wind, \% & 25.9 & 25.5 & 25.1 \\
\hline Temp, F & 2098 & 2089 & 2059 \\
\hline Moist., Grs/SCF & 22.9 & 21.2 & 21.0 \\
\hline Flame Temp, $F$ & 3854 & 3836 & 3897 \\
\hline Top Temp, F & 265 & 263 & 259 \\
\hline Top Press, psig & 16.5 & 16.7 & 17.0 \\
\hline \multicolumn{4}{|l|}{ Coke: } \\
\hline $\mathrm{H} 2 \mathrm{O}, \%$ & 4.7 & 4.7 & 4.9 \\
\hline \multicolumn{4}{|l|}{ Hot Metal, \%: } \\
\hline Silicon & .48 & .49 & .52 \\
\hline Standard Dev. & .102 & .104 & .097 \\
\hline Sulfur & .040 & .041 & .036 \\
\hline Standard Dev. & .012 & .016 & .014 \\
\hline Phos. & .058 & .058 & .060 \\
\hline $\mathrm{Mn}$ & .37 & .37 & .39 \\
\hline Temp., $F$ & 2661 & 2652 & 2681 \\
\hline \multicolumn{4}{|l|}{ Slag. \%: } \\
\hline $\mathrm{SiO} 2$ & 37.12 & 37.30 & 37.17 \\
\hline $\mathrm{Al} 2 \mathrm{O} 3$ & 9.79 & 9.47 & 9.63 \\
\hline $\mathrm{CaO}$ & 39.92 & 40.09 & 39.82 \\
\hline $\mathrm{MgO}$ & 11.36 & 11.36 & 11.49 \\
\hline $\mathrm{Mn}$ & .35 & .36 & .38 \\
\hline Sul & 1.46 & 1.45 & 1.47 \\
\hline$B / A$ & 1.09 & 1.10 & 1.10 \\
\hline$B / S$ & 1.38 & 1.38 & 1.38 \\
\hline Volume, Ibs/NTHM & 432 & 430 & 434 \\
\hline
\end{tabular}




\section{STATISTICAL ANALYSIS OF C FURNACE PERMEABILITY \& COKE CHANGES}

\begin{tabular}{|c|c|c|c|c|c|c|c|c|c|c|c|}
\hline $\begin{array}{c}\text { Trial Period } \\
1998\end{array}$ & & $\begin{array}{c}\text { Coal Irjection } \\
\text { Ra:e }\end{array}$ & $\begin{array}{c}\% \text { Chinese } \\
\text { Coke }\end{array}$ & $\begin{array}{c}\% \text { LV Coal } \\
\text { in Blend }\end{array}$ & $\frac{\text { Burns Harbor }}{\text { Mean Stability }}$ & $\begin{array}{c}\text { Coke } \\
\text { Std.Dev }\end{array}$ & $\begin{array}{c}\text { Permeability } \\
\text { Mean }\end{array}$ & $\begin{array}{l}\text { Standard } \\
\text { Deviation }\end{array}$ & Sample Size & i-Value & $\begin{array}{c}\text { Sigr : zant } \Omega \\
\vdots:\end{array}$ \\
\hline $4 / 1 / \cdot 5 / 17$ & BASE & 297 & 0 & 25 & $60.8,60.9$ & $.78, .93$ & 1.21 & .052 & 40 & - & \\
\hline $5 / 19-6 / 29$ & $\# 1$ & 294 & 0 & 30 & $61.6,62.1$ & $1.31, .87$ & 1.28 & .058 & 34 & 5.00 & 39 \\
\hline $7 / 5-9 / 11$ & $\# 2$ & 300 & 13.8 & 30 & 62.8 & .73 & 1.34 & .067 & 56 & 4.29 & 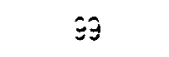 \\
\hline $9 / 13 \cdot 9 / 30$ & $\# 3$ & 240 & 15.1 & 25 & 62.7 & .49 & 1.40 & .079 & 12 & 2.73 & $\cong 9$ \\
\hline
\end{tabular}

\section{ATTRIBUTES OF CHINESE COKE \\ Coke Sizing and Stability}

\begin{tabular}{|c|c|c|c|c|c|c|}
\hline \multicolumn{7}{|c|}{ Chinese Coke Sizing ( Samples from Indiana Harbor to Burns Harbor) } \\
\hline Date & $+4^{\prime \prime} \%$ & $+3 " \%$ & $+2^{\prime \prime} \%$ & $+1^{\prime \prime} \%$ & $-1-\%$ & Stability \\
\hline June 1 & & 11.5 & 48.6 & 35.0 & 4.9 & 68.9 \\
\hline June 2 & & 16.5 & 62.8 & 17.5 & 3.2 & 70.2 \\
\hline June 9 & 0.3 & 13.6 & 69.2 & 15.7 & $: .1$ & 68.0 \\
\hline June 11 & & 13.1 & 64.0 & 21.6 & .2 & 68.9 \\
\hline June 12 & & 10.6 & 61.9 & 24.8 & 2.7 & 69.3 \\
\hline June 15 & & 9.9 & 58.5 & 29.3 & 2.2 & 63.6 \\
\hline June 16 & & 9.9 & 55.2 & 31.4 & 3.5 & 64.5 \\
\hline June 29 & & 5.3 & 57.3 & 35.2 & 2.2 & 70.4 \\
\hline June 30 & & 7.2 & 61.2 & 29.4 & $\cdot .6$ & 70.9 \\
\hline July 1 & 0.4 & 9.6 & 65.1 & 23.6 & $\cdot .3$ & 70.4 \\
\hline July 2 & & 5.4 & 59.3 & 33.5 & $\cdot 3$ & 68.2 \\
\hline July 3 & & 9.5 & 61.0 & 26.7 & 2.7 & 70.7 \\
\hline July 6 & & 3.5 & 53.3 & 38.1 & $\vdots i$ & 67.3 \\
\hline July 7 & & 10.4 & 65.0 & 22.9 & $\cdot 3$ & 71.8 \\
\hline July 9 & & 6.6 & 65.5 & 26.4 & $\cdot 5$ & 71.6 \\
\hline July 9 & 0.4 & 9.6 & 65.1 & 23.6 & $\cdot 3$ & 70.4 \\
\hline July 14 & & 6.9 & 64.3 & 27.6 & .2 & 68.2 \\
\hline July 16 & & 3.5 & 53.3 & 38.1 & 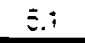 & 67.3 \\
\hline AVERAGE & 0.35 & 9.0 & 60.6 & 27.8 & 25 & 68.9 \\
\hline
\end{tabular}




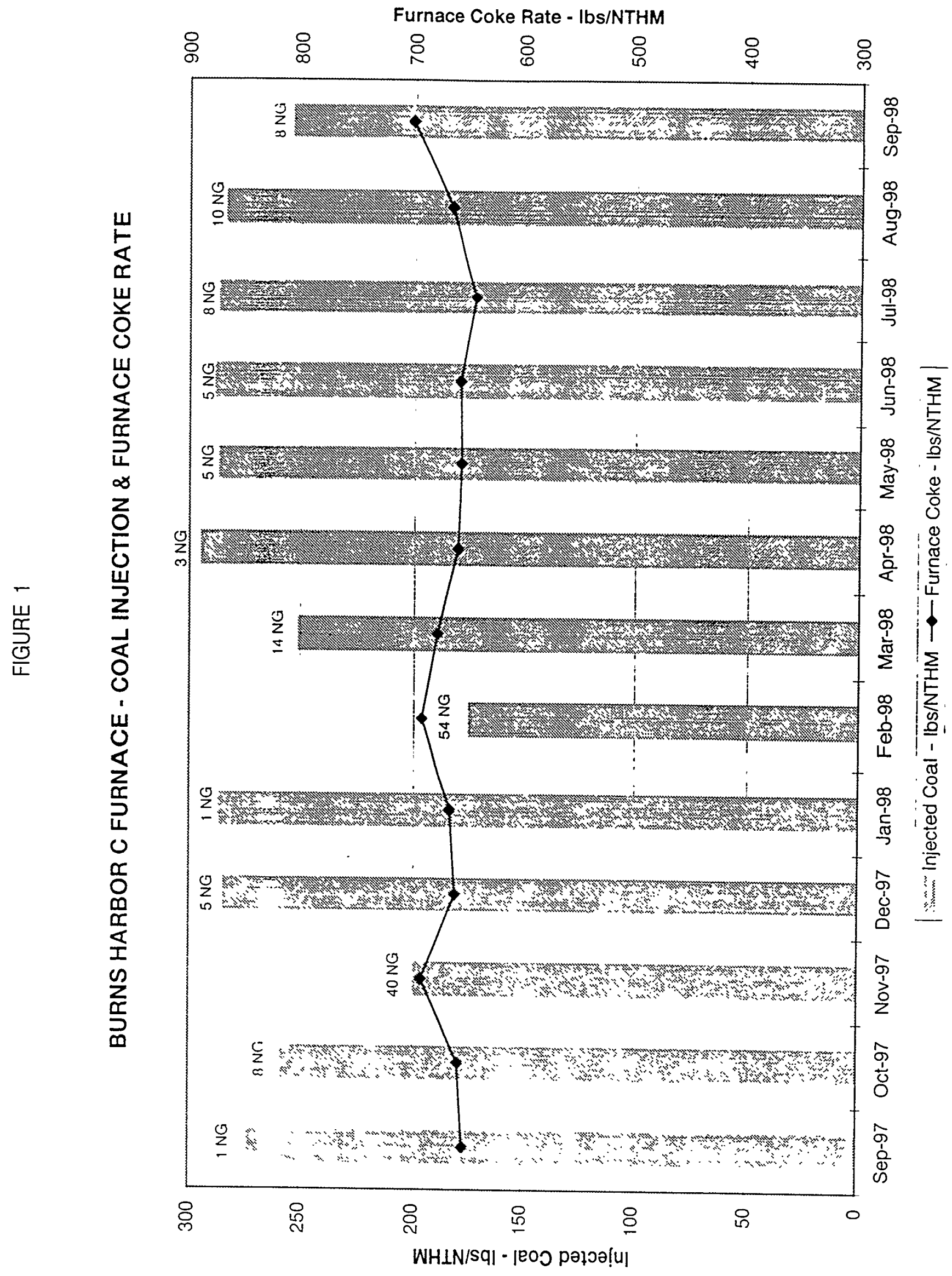




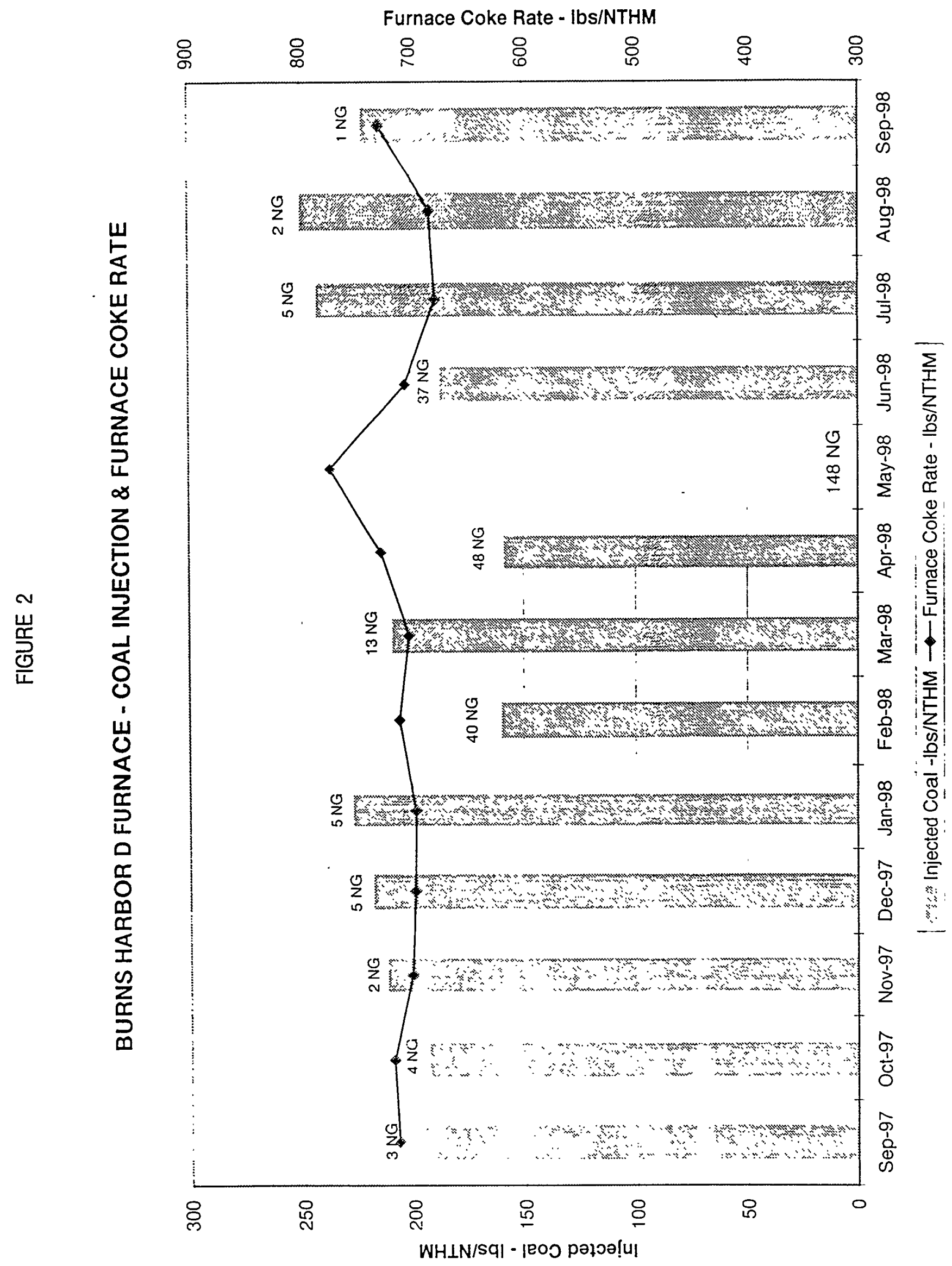




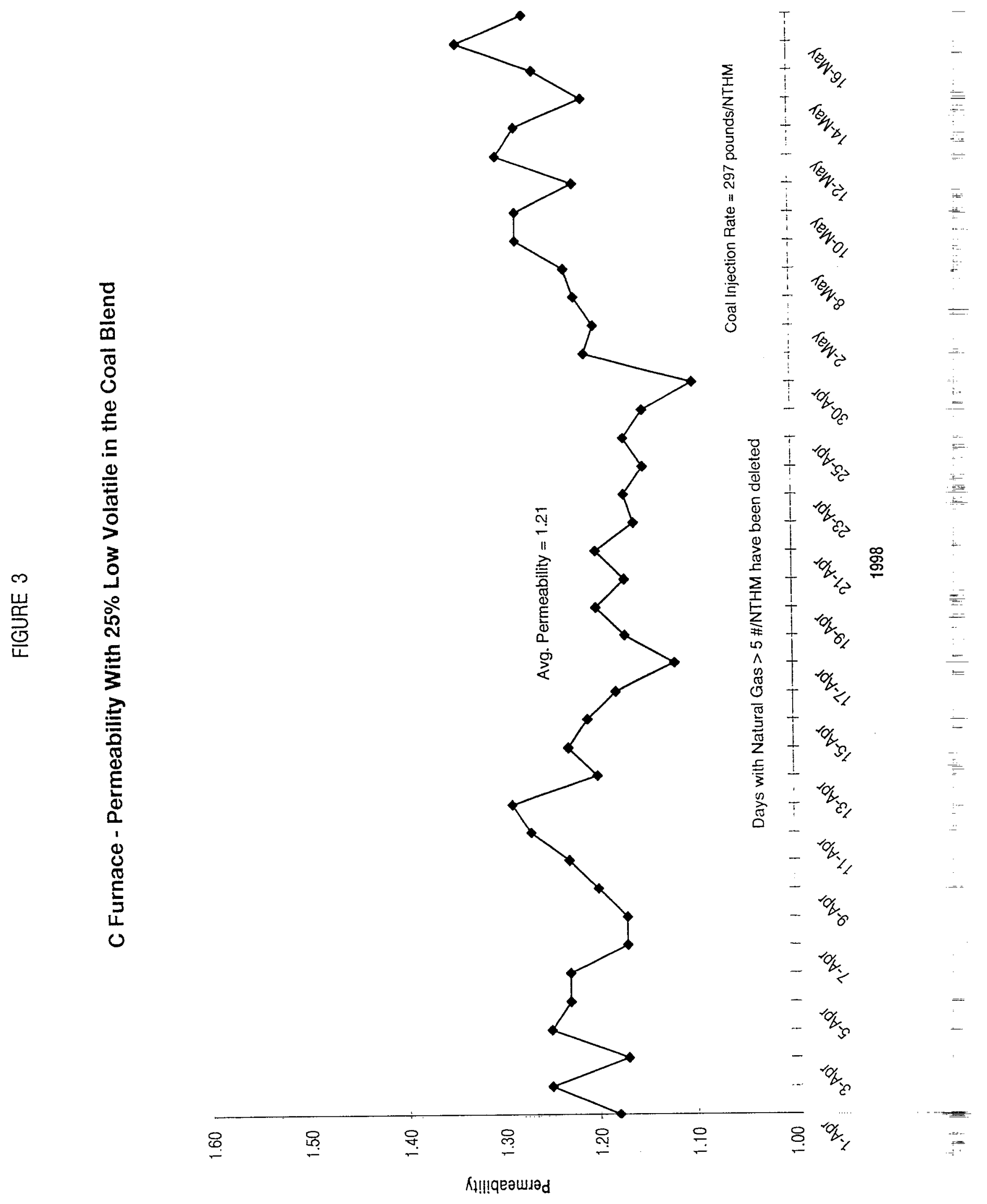


FIGURE 4

C Furnace - Permeability With $30 \%$ Low Volatile Coal in the Coal Blend

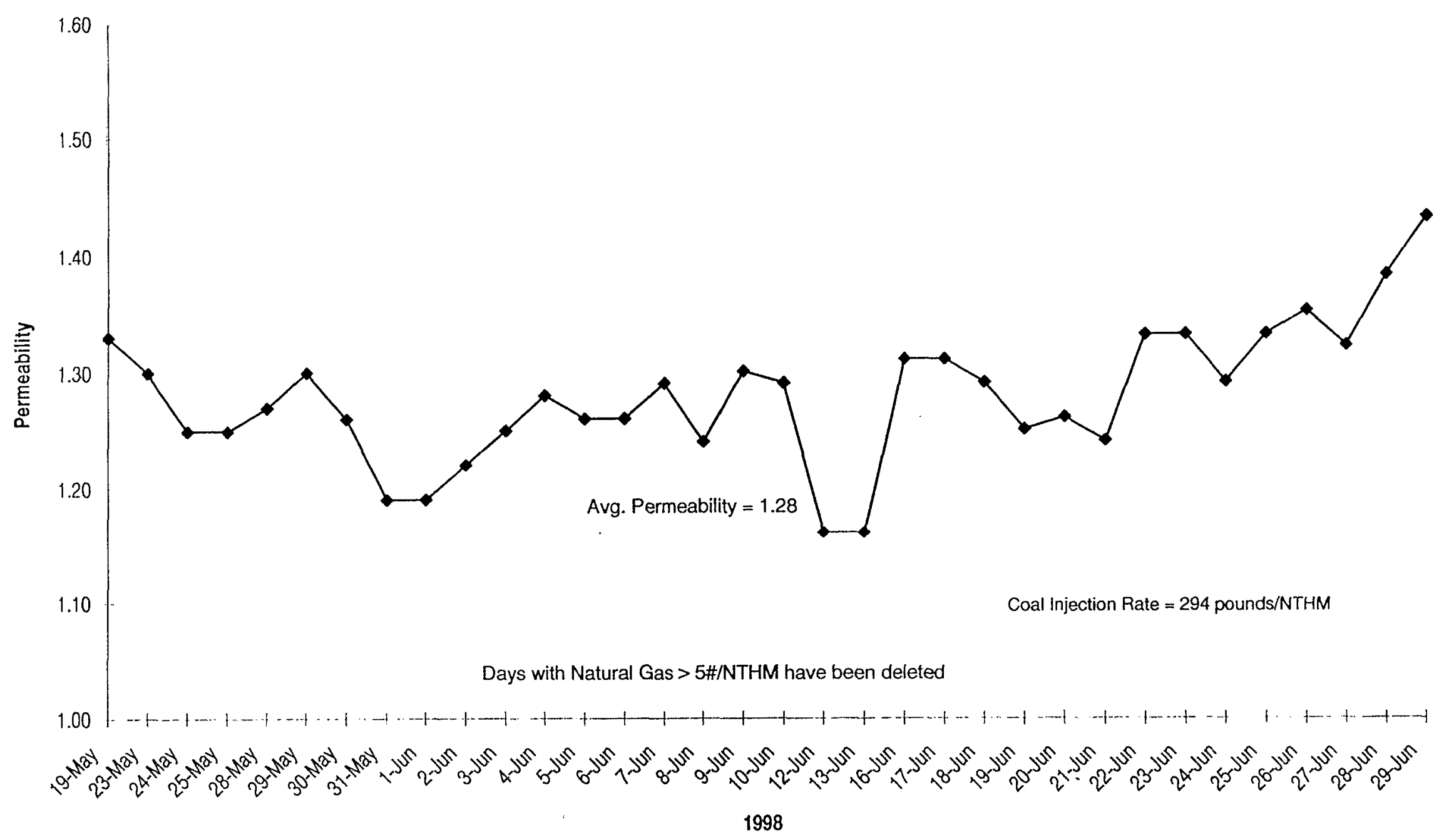




\section{Furnace Permeability with $30 \%$ Low Volatile Coal \& Chinese Coke}

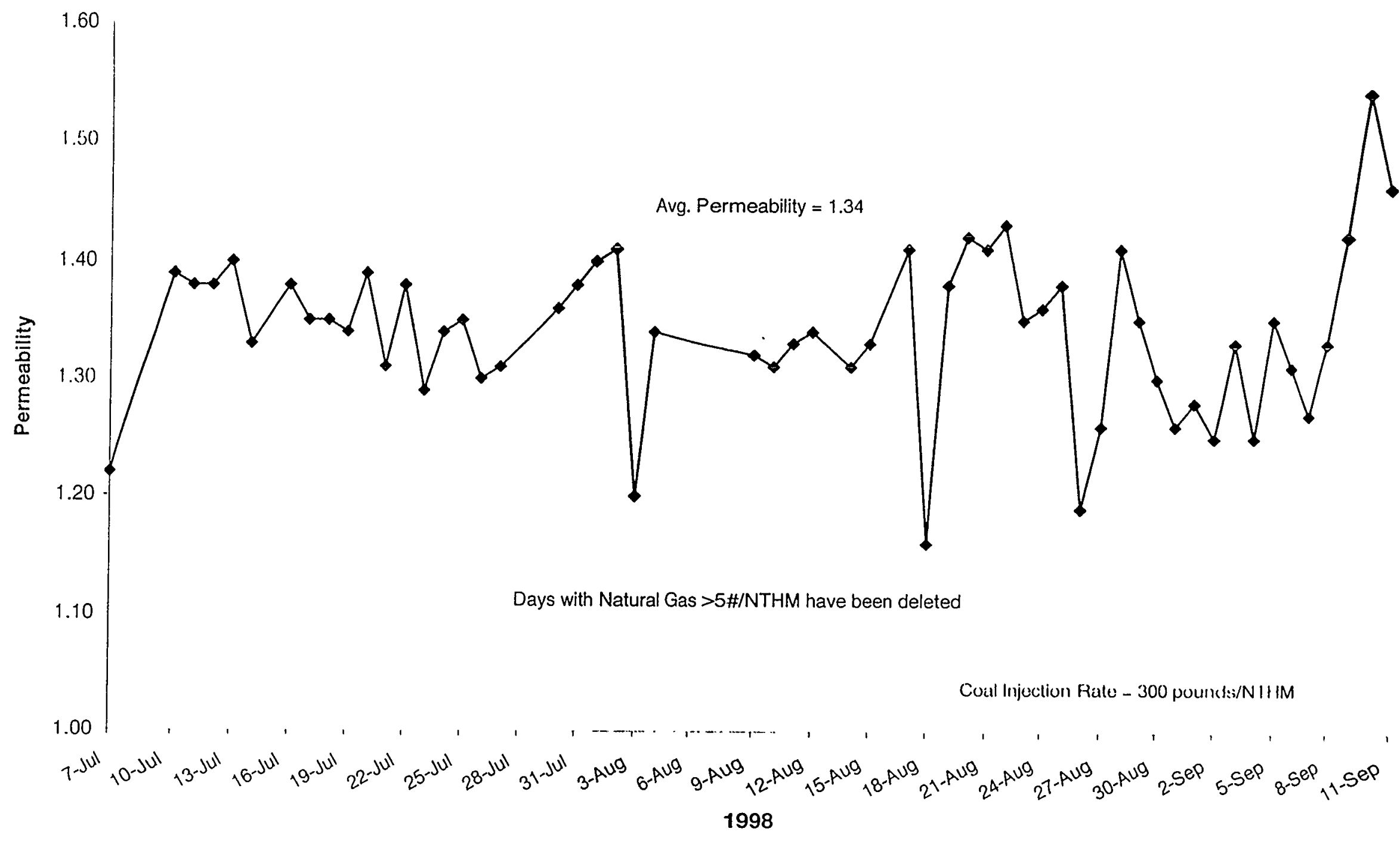


FIGURE 6

C Furnace - Permeability with $25 \%$ Low Volatile Coal \& Chinese Coke

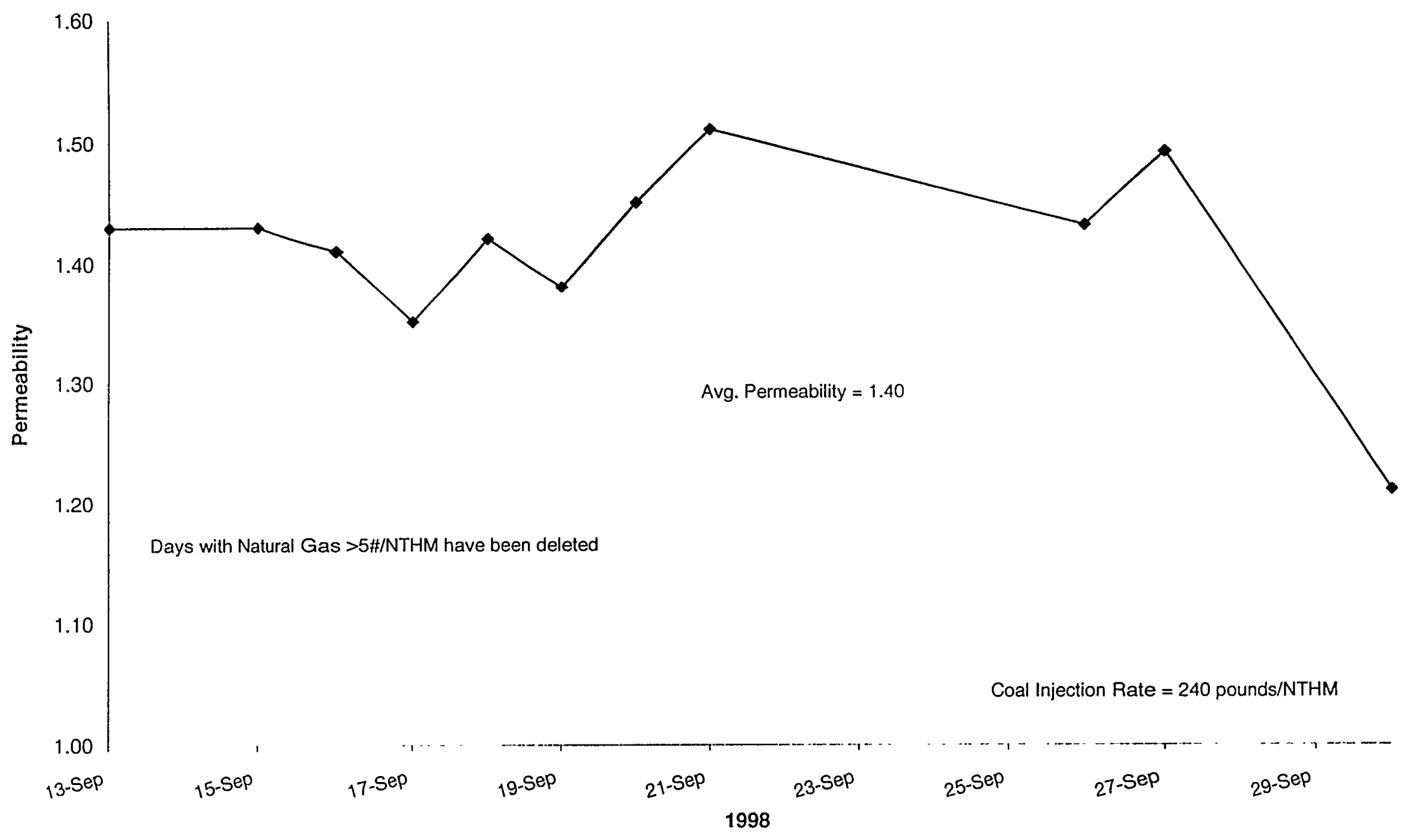

